\title{
Geotechnical Investigations- A Tool for Deciding Mining Method for Chromite Deposits in Odisha State, India
}

\author{
A. Santharam ${ }^{1, *}$ and Kandula Vishnu Vardhana $\mathrm{Rao}^{2}$ \\ ${ }^{1}$ Regional Mining Geologist (Retd), Indian Bureau of Mines, India \\ ${ }^{2}$ Research Scholar, Department of Geology, Andhra University, India
}

\begin{abstract}
The Chromite deposits of Sukinda valley, Odisha, India are of strategic importance for the development of ferro-alloy industries. Around $90 \%$ of the India's chromite ore production derived from two important chromite bearing belts, namely the Baula-Nuasahi belt and Sukinda valley ultramafic complex deposit. In terms of rock strength properties, the host rocks and ore body at Baula -Nuasahi chromite belt are hard and compact, with some structural defects such as joints, faults and dykes. After extracting the chromite ore by surface mining up to the economic pit bottom, the remaining reserves were being mined by underground method. In the Sukinda valley chromite deposits, both the wall rocks and ore body are weak, highly weathered. These mines were operated by opencast method. As most of the working mines in Sukinda valley reached their economic pit limit and there is no further scope to extract the ore by opencast mining. Since the chromite ore bodies are having considerable mineable strike length, width, and depth persistence, there is no option except to convert them into underground mines to increase the life of the mines.

The chromite ore bodies were proved up to depth of $270 \mathrm{~m}$ by exploratory drilling. Some major mining companies are planning for underground mining operations, due to constraint of limited space available for waste dumping, working with common lease boundary, slope instability, high volume of stripping ratio. To overcome such problems, the basic step is to conduct the detailed geo-technical investigations to avoid any unexpected consequences during mine development and stoping operations. The geo-technical investigations comprised of geotechnical mapping of existing mined out benches using scan line surveys, geo-technical drilling and logging of cores for the estimation of RQD, structural discontinuities, testing of cores for material properties followed by performing numerical modeling to evolve a suitable stoping method and excavation geometry.

The paper deals with the results of the geo-technical investigations carried out for the planning and design of underground mine workings, design of stope parameters based on the geo-mining conditions.
\end{abstract}

Keywords: Stripping ratio, numerical modeling, stope design, stoping method, chromite deposits.

\section{INTRODUCTION}

The Chromite deposits of Sukinda and BoulaNuasahi of Odisha, India are of strategic importance for the development of ferrochrome industry in India. Earlier, these chromite deposits were being operated by opencast mining method, and most of these mines have gone deeper beyond the economic pit limits. As a result some of the mines are in the process for developing underground mining method. Thus, there is an urgent need for conducting geo-technical investigations to develop a proper stoping method for the extraction of chromite lodes. The Geomechanical properties of hanging wall, foot wall and the ore zone plays an integral part in evaluating the suitability of stoping method and proposed rate of extraction with safety considerations.

\section{MINE GEOLOGY}

Bangur chromite deposit is located on the southwestern part of Baula-Nuasahi Ultramafic

*Address correspondence to this author at The Regional Mining Geologist (Retd), Indian Bureau of Mines, India; E-mail: asantharam33@gmail.com; geologistvishnu@gmail.com complex. The chromite bearing formation occurs in the ultra basics represented by serpentinite, talcserpentinite, and talc-tremolite schist with small veins of asbestos. These have been intruded by basic intrusions such as dolerite and gabbro. The general trend of the ultra basic rocks is NNW-SSE with dips $70^{\circ}$ to $80^{\circ}$ towards NE. These ultramafic rocks are partially altered. The chromite mineralisation is mainly controlled by lithology and its structural variants.

The major rock types exposed in the area comprise of Gabbro and serpentinite in the hanging wall and Gabbro and pyroxenite in the footwall formations. Gabbro is dark coloured, coarse-grained rock containing plagioclase feldspar as major constituent. Fine-grained serpentinites with talc and asbestos are also observed at some places in the underground workings. Serpentinite is fine-grained altered product of peridotite-chromite suite of rocks. It essentially comprises of serpentine, with conchoidal fracture. It is hard in nature and soft when intensely weathered. Dolerite is exposed in the form of intrusive dyke intersecting the Gabbro and serpentinite rock formations. (Figure 1) 


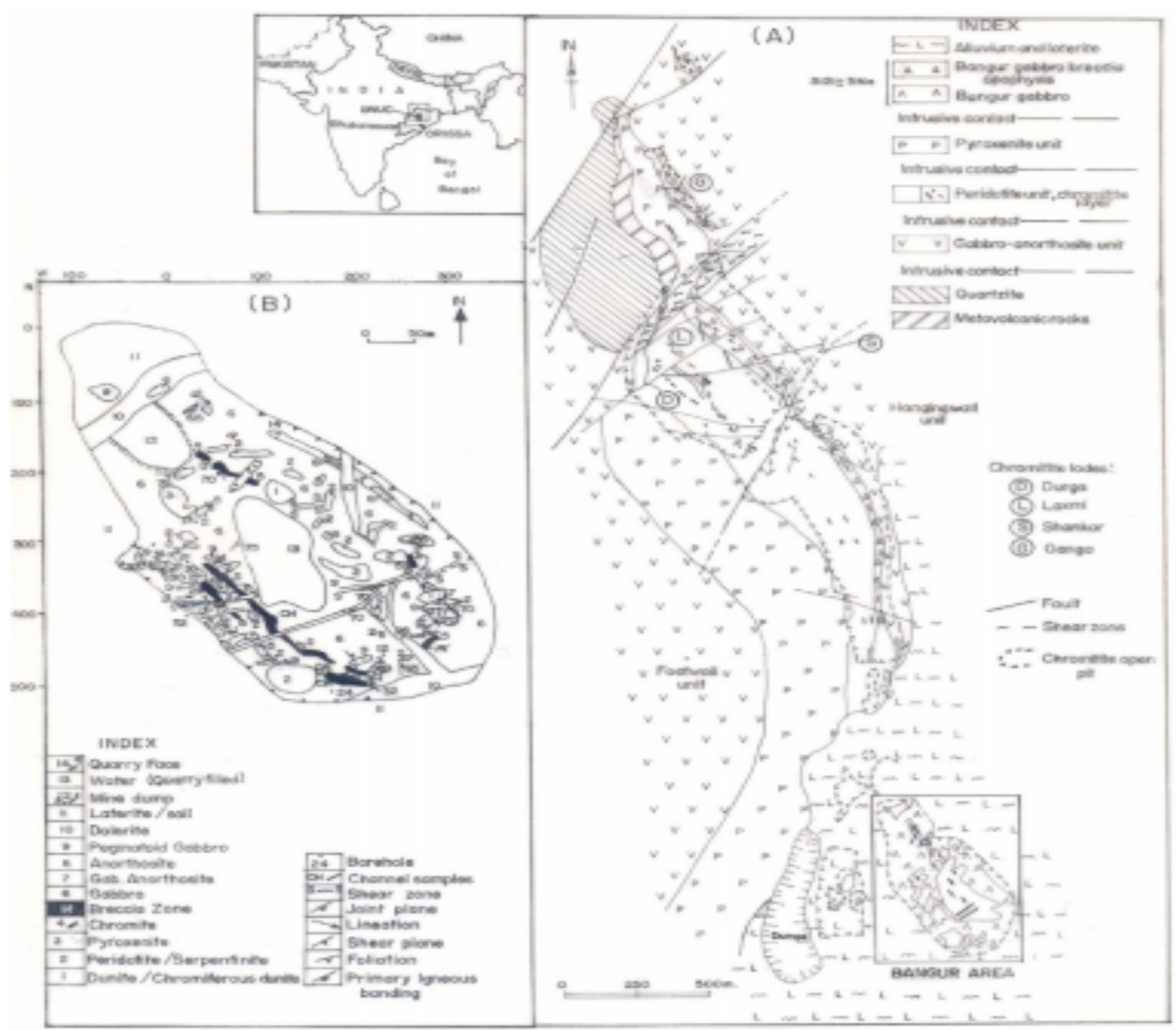

Figure 1: Geological map of Baula-Nuasahi-Bangur ultramafic complex ( K.C.Sahoo, et al. 2014).

\subsection{Nature Of Chromite Mineralisation}

The chromite ore bodies are confined to the altered peridotite-dunite suite of rocks. Due to extensive folding I faulting, the ore bodies appear as discontinuous, isolated and lensoid type. Chromite occurs in disconnected lensoid bands trending N-S in the northern and north central part, and NNW-SSE in the southern part confirming to the general foliation trend of the country rock.

Three types of Chromite ore occur at Bangur area namely,

1. Hard Massive Ore - hard, massive, compact, lumpy, steel grey colour and sometimes granular in nature.
2. Spotted / Disseminated - transitional type, disseminated and at times massive in nature.

3. Friable Ore - brown to black in colour, loosely bonded, medium to coarse grained, friable in nature.

These chromite ore bodies are confined to altered ultrabasic rocks and occur as disconnected lenses trending N-S in the southern part, and NNW-SSE with dips $65^{\circ} \mathrm{E}$ to $80^{\circ}$ in the northern part conforming to the foliation of the country rock. Three sets of joints are observed in dolerite and gabbro. The joint types include oblique joints, vertical joints and bedding planes. The major structure of this deposit comprise of a southwesterly plunging syncline. Typical chemical analysis of different types of chromite ore, The ore 
bodies are having thickness of $5-10 \mathrm{~m}$ in the BaulaNuasahi chromite belt. The chromite deposits of BaulaNuasahi on the other hand are hard and lumpy in nature, having good grade with favorable $\mathrm{Cr}$ : Fe ratio with competent wall rocks which are suitable for underground mining.

\subsection{Need For Converting from Opencast to Underground Mining}

Most of the Chromite mines in Sukinda valley are being operated by opencast mining, due to relatively ease in mining conditions with high level of productivity. However, most of these mines have reached its economic pit bottom, High volume of stripping ratios, constraint of available space for dumping overburden, environmental considerations necessitate the conversion of opencast mining into underground mining. The difficulty lies with mining these lode type deposits having weak wall rocks by underground mining, which is a challenging task. As of now, there are no well tested stoping methods available to implement such practices.

While the appeal for surface mining lies in mass production and minimal cost of production, the underground mining stems from the variety of it methods to meet conditions demanding safety and productivity including environmental considerations. The technical parameters include cut-off grade, economic pit bottom from surface, depth persistence of the ore body from surface, ore body geometry at various cut-off values, geo-technical and geohydrological data and beneficiation characteristics. These input form the basis for feasibility studies and finalization of underground mining plans and layouts.

\section{GEOTECHNICAL INVESTIGATIONS}

Geo-technical investigations form an integral part during the planning and design of surface and underground mines. Lack of geo-technical data during the initial stage of the mining project may lead to unexpected consequences. Therefore, it is necessary to collect or generate the geo-technical data from the start up of the project till its completion. The geotechnical site investigations include geo-technical drilling, estimation of Rock Mass Quality (RQD) from the drill cores, testing of core samples for uniaxial compressive strength, tensile strength, young's modulus, poison's ratio, permeability and porosity measurements. Detailed geo-technical mapping of the discontinuities using scan line surveys, analysis of structural data using stereonets, rock mass characterization using different geo -mechanics classification systems.

The hydrogeology also plays a major role in developing the underground mining project. It is essential to understand the surface and ground water regime of the area. In some locations, it is advisable to conduct packer tests to gain a better understanding of the formation characteristics in terms of ground water regime. The measurement of stress regime of the area is very important in case of deep mining proposals. The measurement of in-situ stresses, their magnitude, and direction will provide valuable information on stress regime of the area in which the underground mining operations are planned. Even though, the determination of in-situ stress experiments are expensive, but they provides a valuable input on for numerical stress analysis. The sets of data acquisition required for the geo-technical assessment are summerised in Table 1. (Figure 2)

Table 1: Sets of Data Acquisition for Geotechnical Assessment

\begin{tabular}{|c|c|c|c|c|}
\hline Mining Environment & $\begin{array}{c}\text { Rock Mass } \\
\text { Characterization }\end{array}$ & $\begin{array}{l}\text { In-situ stress } \\
\text { analysis }\end{array}$ & $\begin{array}{l}\text { Mining Method } \\
\text { designs }\end{array}$ & $\begin{array}{l}\text { Monitoring } \\
\text { Programme }\end{array}$ \\
\hline Geological Setting & $\begin{array}{l}\text { Intact rock mass } \\
\text { strength properties }\end{array}$ & Numerical Methods & $\begin{array}{l}\text { Selection of proper } \\
\text { mining method }\end{array}$ & $\begin{array}{l}\text { Geo-technical instrumentation for } \\
\text { monitoring strata behaviour } \\
\text { during progress of mining }\end{array}$ \\
\hline Hydrology & Discontinuity data & $\begin{array}{l}\text { Structural tests for } \\
\text { stability }\end{array}$ & $\begin{array}{l}\text { Ore extraction } \\
\text { sequencing }\end{array}$ & $\begin{array}{c}\text { Ground water and surface water } \\
\text { monitoring }\end{array}$ \\
\hline \multirow[t]{3}{*}{ Mining History } & Rock Mass Quality, & $\begin{array}{l}\text { Empirical } \\
\text { techniques }\end{array}$ & $\begin{array}{l}\text { Blasting and rock } \\
\text { breaking }\end{array}$ & Blast Vibrations \\
\hline & & & $\begin{array}{l}\text { Choice of support } \\
\text { design }\end{array}$ & $\begin{array}{c}\text { Design Performance and } \\
\text { evaluation }\end{array}$ \\
\hline & & & $\begin{array}{l}\text { Primary development, } \\
\text { mine drainage }\end{array}$ & \\
\hline
\end{tabular}




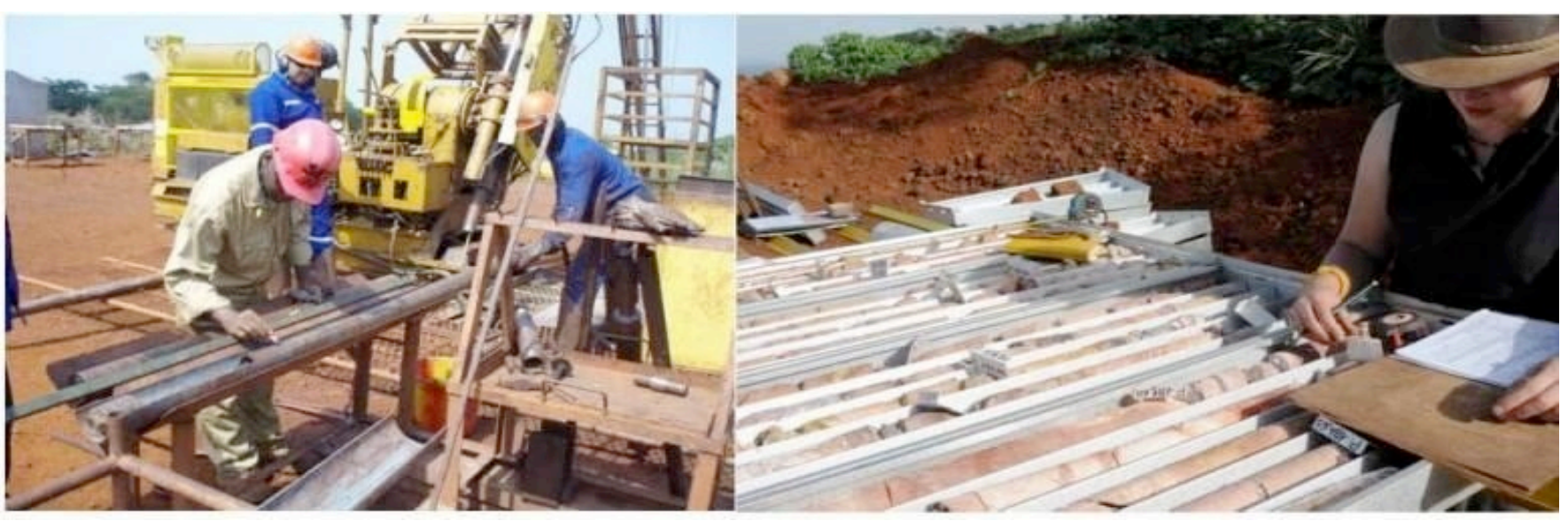

Figure 2: Geotechnical Drilling and Measurement of RQD from drill cores.

\subsection{Mine Development}

The Bangur chromite deposit was worked by opencast method till 1980. Later, the management switched on to underground mine development by driving two inclines namely incline No. 1 and 2 from the surface at a distance of $200 \mathrm{~m}$ from the main pit, which is at present not in operation. These inclines were driven from the surface to develop ' 0 ' $\mathrm{mRL}$ and +30 $\mathrm{mRL}$. At present at $-30 \mathrm{mRL}$ level development is in progress. The level development has been kept $30 \mathrm{~m}$ apart, having connection with both the inclines.

Both the inclines have been furnished with ladder ways for the movement of the personnel. Mechanical hoisting system has been installed in the incline No.1 for hoisting ore and waste material to the surface. During progress of mine development a major fault zone trending $\mathrm{N} 55^{\circ} \mathrm{E}-\mathrm{S} 55^{\circ} \mathrm{W}$, dipping $50^{\circ}$ to $60^{\circ} \mathrm{NW}$ has been intersected. Geotechnical assessment of the fault zone indicated the immediate ground support. Accordingly, the entire fault zone has been supported by iron girders with timber laggings. At some places, the minor inflow of seepage water observed along the fault zone. The roof and back portions of the underground openings were supported by grouted rock bolts, at $1.5 \mathrm{~m} \times 1.5 \mathrm{~m}$ spacing.

\subsection{Review of Strata Conditions}

During the period of investigation, level development is in progress at ' 0 ' $\mathrm{mRL}$ and $+30 \mathrm{mRL}$. The height and width of drives and crosscuts varied from $2 \mathrm{~m}$ to $3 \mathrm{~m}$. The levels were developed along NWSE direction following the general strike direction of the chromite bands. It was observed that the roof and sidewalls of the levels are quite competent with minor structural defects. Some of the discontinuities are weathered and altered with in-fill gouge material. At some places, where the strata conditions are weak, the immediate roof portion being supported by rock bolts with timber lagging during development

\subsection{Geomechanics Classification}

The purpose of generating data on discontinuities is to produce detailed level-wise geo-technical maps, which represent a permanent record of existing ground conditions in the underground workings prior to commencement of stoping. The data will allow comparisons to be made between the existing ground conditions and to assist in delineating areas, which may require support during progress of stoping. The geo-technical data thus generated will also be used to evaluate support requirements employing quantitative judgment and making comparison with empirical systems in vogue.

Detailed scan line surveys were carried out in the levels and crosscuts where 'trial stope' development has been proposed. The purpose of geo-technical mapping aimed at in understanding the existing and envisaged rock mass conditions at $0 \mathrm{mRL}$ and $30 \mathrm{mRL}$. All the prominent discontinuities, that are exposed in the roof, side walls were carefully mapped on a scale of $1 \mathrm{~cm}=2 \mathrm{~m}$. During scan line surveys the RQD values for each scan line mapped were assigned based on visual assessment.

The computation of ' $Q$ ' and RMR values were based on the input data generated which include intact rock strength, discontinuity spacing, roughness, alteration, RQD, ground water conditions. Separate computations were made for each rock type, to classify them into standard geo-mechanics classification. The computed values of "Q" and "RMR" values obtained at 
Table 2: Summary of Average Values of Different Tests Performed

\begin{tabular}{|c|c|c|c|c|c|c|c|}
\hline Sr. No. & Rock Type & $\begin{array}{l}\text { U C S } \\
\text { (Mpa) }\end{array}$ & $\begin{array}{c}\text { Brazilian } \\
\text { Tensile } \\
\text { Strength (Mpa) }\end{array}$ & $\begin{array}{c}\text { Density } \\
\mathrm{Kg} / \mathrm{m}^{3}\end{array}$ & $\begin{array}{l}\text { Shear } \\
\text { Strength } \\
\text { (Mpa) } \\
\text { (Punch) }\end{array}$ & $\begin{array}{l}\text { Young's } \\
\text { Modulus } \\
\text { (Gpa) }\end{array}$ & $\begin{array}{c}\text { Poisson's } \\
\text { Ratio }\end{array}$ \\
\hline 1 & Gabbro (GB) & 164.70 & 15.69 & 2865.53 & 35.68 & 0.28 & 11.6 \\
\hline 2 & Talc Serpentine (TS) & 139.74 & 11.18 & 2768.92 & 33.00 & 0.16 & 6.6 \\
\hline 3 & Gabbro / Serpentinite (GBS) & 254.88 & 20.79 & 3044.1 & 33.36 & 0.14 & 6.8 \\
\hline 4 & Chromite (CR) & 58.30 & 5.73 & 3940.72 & 12.30 & 0.12 & 6.4 \\
\hline 5 & Serpentinite (SERP) & 44.10 & 4.96 & 2591.5 & 25.00 & 0.13 & 7.0 \\
\hline 6 & Gabbro with sulphide mineral (GBSM) & 136.43 & 15.38 & 3183.55 & 31.91 & & \\
\hline 7 & Dolerite (DOL) & 210.22 & 18.50 & 2898.88 & 20.08 & 0.17 & 9.3 \\
\hline
\end{tabular}

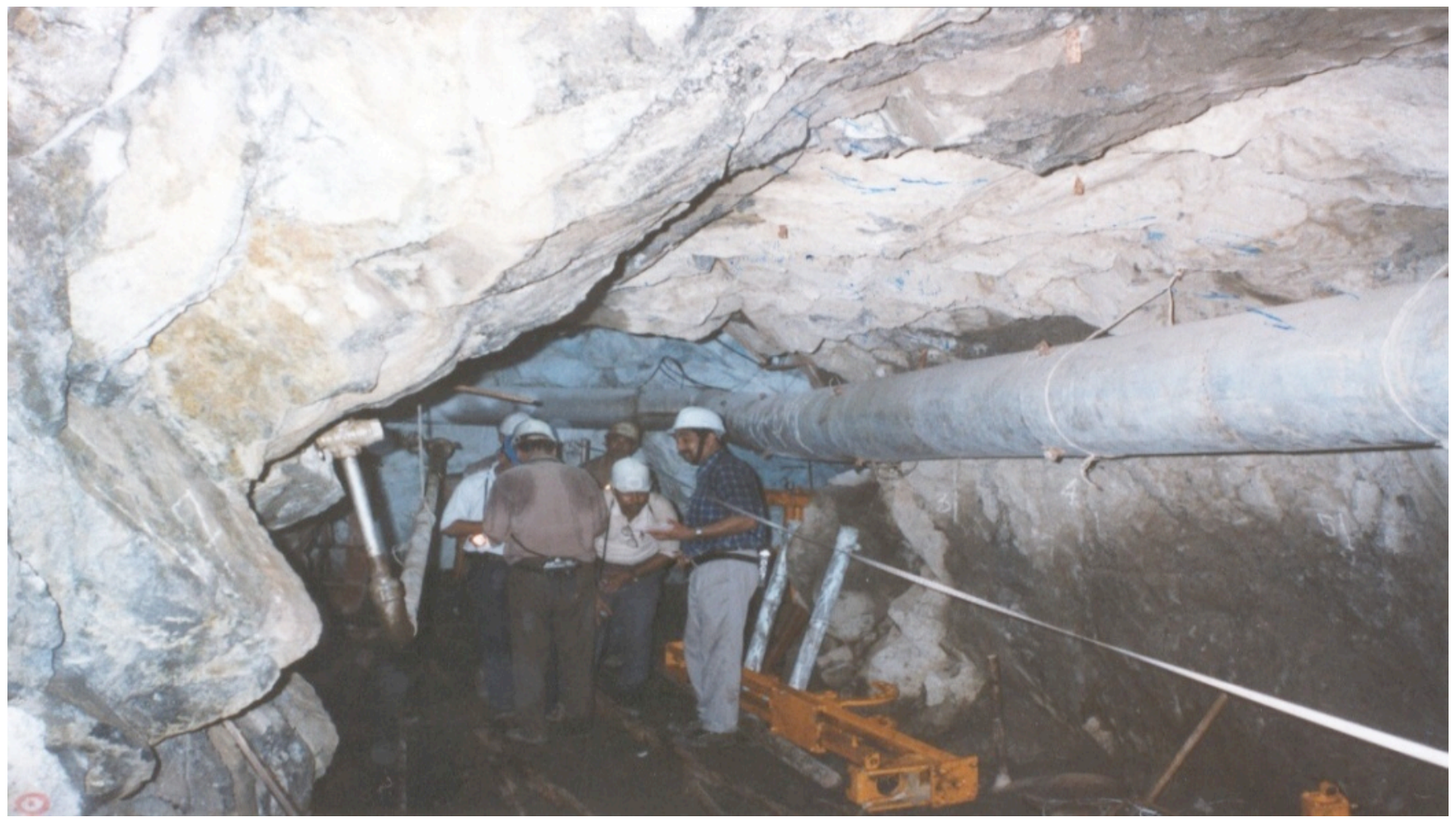

Figure 3: Scan line surveys for mapping joints in underground.

$0 \mathrm{MRL}$ and $30 \mathrm{MRL}$ falls under "Fair " and "Good" category as per the Geomechanics Classification system. (Bieniawski, Z.T. 1989).

Representative drill core samples were tested for their Physico-mechanical properties and the values obtained were Summerised in Table 2. (Figure 3)

\subsection{Geomechanical Properties}

For obtaining the geo-mechanical properties of chromite ore zone, and the footwall and hanging wall formations, several core samples were tested in the laboratory for the material properties. In the study area four rock types are encountered namely: gabbro, serpentine, marketable ore and subgrade ore. However, for model with out post pillar, modulus of elasticity of each rock mass is taken to be $40 \%$ and $20 \%$ of the tested value for RMR of 70 and 50 respectively based on Hoek and Brown criteria. Table 3 shows the of material properties values used in finite element models. Table 4 provides the summary of elastic properties of intact rock and corresponding Rock Mass Rating (RMR) values used for Finite Element Modelling (FEM) analysis. 
Table 3: Material Properties for Different Values of RMR for the Finite Element Modeling

\begin{tabular}{|c|c|c|c|c|c|}
\hline Rock type & $\begin{array}{l}\text { Modulus of Elasticity } \\
{ }^{*}(\mathrm{GPa})\end{array}$ & $\begin{array}{l}\text { Poisson's } \\
\text { Ratio }\end{array}$ & Density $\left(\mathbf{k g} / \mathbf{m}^{3}\right)$ & $\begin{array}{l}\text { Compressive Strength } \\
{ }_{* *}(\mathrm{MPa})\end{array}$ & $\begin{array}{l}\text { Tensile Strength } \\
{ }_{* *}(\mathrm{MPa})\end{array}$ \\
\hline Serpentine & 7.0 & 0.13 & 2591 & 44.1 & 4.96 \\
\hline Gabbro & 11.6 & 0.28 & 2865 & 164.7 & 15.7 \\
\hline Marketable ore & 6.4 & 0.12 & 3940 & 58.3 & 5.73 \\
\hline Subgrade ore & 4.0 & 0.12 & 3940 & 40.0 & 4.15 \\
\hline
\end{tabular}

${ }^{*}$ Gpa: Giga Pascal, ** Mpa: Mega Pascal.

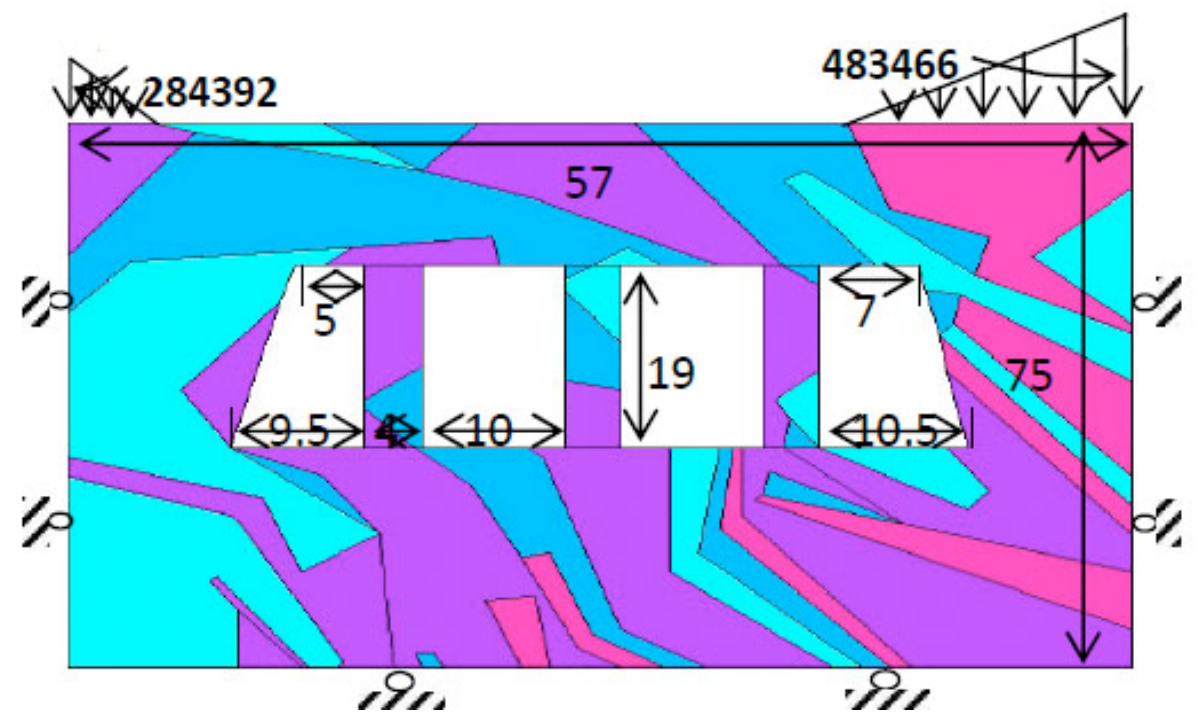

Figure 4: Dimension of stope design.

Table 4: Modulus of Elasticity (GPa) for Different Values of RMR

\begin{tabular}{|c|c|c|c|}
\hline \multirow{2}{*}{ Rock type } & \multicolumn{3}{|c|}{ RMR } \\
\cline { 2 - 4 } & Intact & $\mathbf{7 0}$ & $\mathbf{5 0}$ \\
\hline \hline Serpentine & 7.0 & 2.8 & 1.40 \\
\hline Gabbro & 11.6 & 4.64 & 2.32 \\
\hline Marketable ore & 6.4 & 2.56 & 1.28 \\
\hline Sub-grade ore & 4.0 & 1.60 & 0.8 \\
\hline
\end{tabular}

\section{NUMERICAL MODELING}

Numerical modeling is one of the tools for the analysis for the determination of stresses and displacements in any underground excavation with defined boundary condition. There are several commercial software are available for performing the numerical stress analysis such as FEM and Boundary element method and hybrid methods. In the case of Bangur mine, Finite Element method is used for modeling the shrinkage stope geometry. The basic concept in this approach is that a body or structure can be divided into finite number of small units of finite dimensions called "elements". The model description consist of several elements and the cross sections were analysed using numerical techniques. All the dimension of stope considered considering the material properties and RMR value. The stope has been modeled considering the rib pillar in between the open stope as shown in Figure 4.

The dimensions of the pillar width, length, width and height of the open stope were shown in the designed stope section (Figure 4).

\subsection{Model Without Post Pillar}

The stope was also modeled with out post pillar, and the results of numerical modeling were shown in Figure 5. The tensile zones and highly stressed zones were concentrated towards the corners (abutments) of the stopes. It has been found that the maximum unsupported stope span of over $20 \mathrm{~m}$ considered to be stable. 


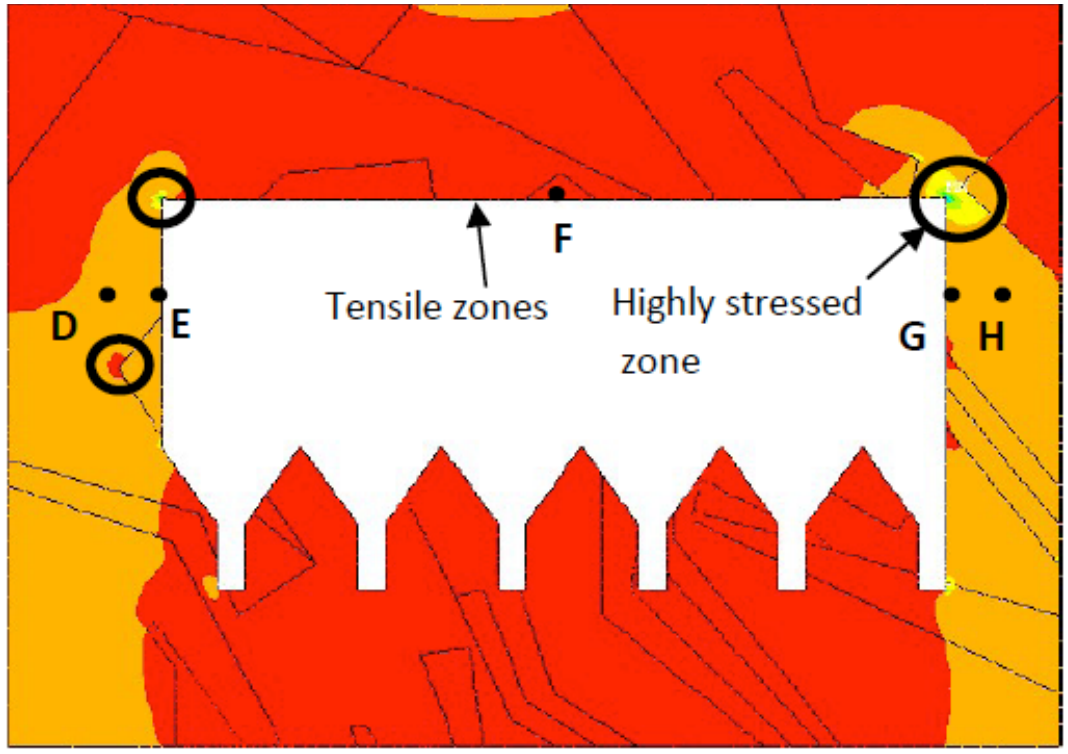

Figure 5: Modeling without post pillar.

\subsection{Factor of Safety}

The factor of safety obtained from numerical modeling varied from 1.30 to 3.51 for RMR value of 70 and for the RMR value of 50 , the Factor of safety varied from 1.15 to 2.96 . Therefore, sublevel stoping with post pillar has been proposed. Since the extraction of chromite has to be done by underground method the parameters such as extraction ratio and width, got direct bearing on pillar size and stress. The stope is modeled with geometrical conditions, to extract the ore in stages. Steep dipping of the ore body and competent hang wall and footwall formations provide favorable conditions for low cost productivity stoping method. The strength parameters of hang wall and footwall formations, ore characteristics and preliminary assessment of existing strata conditions, which in turn favour the sub-level stoping method.

\section{SUBLEVEL OPEN STOPING}

The choice of selection of the proposed stoping is based on the geo-technical data generated and its analysis, which is given as under:

Steep dip - the inclination of the footwall must exceed the angle of repose.

Stable rock in both hanging wall and footwall.

Competent Ore and host rock.

Regular Ore boundaries.

Favourable width of the Ore body.
In Sub level open stoping, Ore is recovered in open stopes after being mined. The Ore body is divided into separate stopes. Between the stopes, Ore sections are set aside for pillars to support the hanging wall. The pillars are normally shaped as vertical beams across the Ore body. Horizontal sections of Ore, known as Crown pillars are also left to support mine workings above producing stopes. The stability of rock mass is a limiting factor to be considered while selecting the sizes of stopes.

\subsection{Rib Pillar Stability Analysis}

The most important criterion is that the pillars remain stable and this will depend on their size, shape, elastic properties, rock mass quality and amount of deformation. It will also depend on the roof and floor rocks and the ratio of span of yielding zone to depth below surface. These above considerations were made, while designing the rib pillar through empirical approach. (Ref: Annexure-5);

- $\quad$ The size of the pillar should be kept wider to avoid failure.

- $\quad$ The pillar has been designed for the Factor of safety of excess of 1.2 for long- term stability.

In a mining environment, pillars are usually in ore and to minimise loss of revenue as a result of "frozen" ore reserves, every effort must be made to minimise the size of the pillars if they are to be permanent. If they are to be extracted at a later date then care must be taken to ensure that they are in a condition 
Table 5: Sensitivity Analysis of Rib Pillar (0MRL to $30 \mathrm{mRL}$ )

\begin{tabular}{|c|c|c|c|c|}
\hline Case & Pillar Width $(\mathbf{m})$ & Pillar Height $(\mathbf{m})$ & Excavation Width $(\mathbf{m})$ & Factor of Safety \\
\hline \hline 1 & 10 & 30 & 15 & 2.96 \\
\hline 2 & 10 & 30 & 20 & 2.02 \\
\hline 3 & 8 & 30 & 20 & 1.49 \\
\hline 4 & 8 & 30 & 15 & 2.21 \\
\hline
\end{tabular}

conducive to efficient extraction at this later stage. They should be large enough not to be highly stressed or they should have been designed to fail partially, consequently relaxing the stresses, whilst maintaining their integrity. The attempts to define width to height ratio $(\mathrm{W} / \mathrm{H})$ for the pillar imply that constraint is taken as necessary to ensure pillar survival.

Pillars can therefore be designed to yield as long as this does not lead to an unstable condition and the possibility of uncontrolled pillar collapse. This depends, to a certain extent, on the ratio of pillar area to depth below surface. However, the load it will or can accept will depend on the strength of the floor and roof material.

The sensitivity analysis of pillar width and its corresponding Factor of Safety is shown in Table $\mathbf{5 .}$

\subsection{Design of Pillar by Mathews Stability Graph}

Two primary factors are used in this design approach: Geometric term that represents pillar shape, and strength term that includes the in-situ rock strength, and the predicted pillar load. In case of mine pillars the more cylinder a pillar, the less confining stress will be available resulting in lower strength. The pillar stability graph was developed by plotting the ratio of pillar load / UCS of intact pillar material against the pillar width / height ratio. The pillar width (Wp) is defined as dimension normal to the direction of induced stress, where as pillar height $(\mathrm{Hp})$ is measured parallel to the induced stress. The pillar load is measured at the core of the pillar where as UCS is recorded for the intact rock comprising the pillar.

In the case of Bangur mine, considering sublevel open stoping method, the pillar width/height ratio for $10 \mathrm{~m}$ wide pillar is 0.33 . The average pillar load / UCS ratio is 0.22 . Therefore, from the pillar stability classification graph, the rib pillar falls under stable category with factor of safety of 1.4. (Hoek \& Brown, 1981).

\subsection{Ground Instrumentation and Monitoring}

It is necessary to monitor the strata conditions during the progress of stoping operations, which require an instrumentation plan. Ground instrumentation include vibrating -wire stress meters, strain gauges, multi-point extensometers, vibrating-wire load cells, piezometers, tape extensometers, convergence indicators etc. Subsidence analysis need to be carried out as a precautionary measure.

\section{RESULTS AND DISCUSSIONS}

Geo-technical investigations form an integral part for the design and planning of underground excavations. Knowledge of stress regime of the area provides the valuable input on in-situ stress, its magnitude, direction for the effective calibration of numerical model. Ground instrumentation is also necessary to measure the change in stress, strain and rock mass deformation and in predicting the strata behavior during progress of mining operations. The geo-technical mapping carried out at ' 0 ' $\mathrm{mRL}$ and +30 $\mathrm{mRL}$ revealed that the rock mass conditions in the underground excavations falls under FAIR category with an RMR value of 65 and ' $Q$ ' value of 10 - 14. The physico-mechanical properties of footwall, ore body and hanging wall are relatively hard and compact. The range of UCS values for Gabbro varied from 155.48 Mpa to $190.35 \mathrm{Mpa}$. Similarly, the range of UCS values for talc-serpentinite varied from $132 \mathrm{Mpa}$ to $147 \mathrm{Mpa}$. In the case of Dolerite, the values varied from 180.11 to 249.04 Mpa. The values of cohesion and angle of internal friction also support the stability of the rock mass.

The maximum stope width works out to be $20 \mathrm{~m}$. and the height of the rib pillar works out to be $30 \mathrm{~m}$. with its corresponding factor of safety of more than 1.2.

Similarly, the stope height can be kept up to $30 \mathrm{~m}$ which may not likely to cause any instability. Considering the rock mass properties, results of numerical modeling analysis, sub level stoping method 
is economically viable due to the wide ore body, favorable dip and competent wall rocks.

\section{REFERNCES}

[1] Biensawski ZT. Engineering Rock Mass Classification, John Wiley and Sons 1989.

[2] Hoek E and Brown ET. Underground Excavations in Rocks, Institute of Minning and Metallurgy 1981.

[3] Report on Geo-technical investigations at Bangur Chromite mine. Odisha, M/s. Orissa Mining Corporation, Mining Research Cell, Indian Bureau of Mines, Nagpur (unpublished).

[4] Report on Rock testing and numerical modeling for stope design, Bangur Chromite mine, Department of Mining Engineering, IIT, Kharagpur, (Unpublished) 2004.

[5] Santharam A. Ground Monitoring at Mochia Mine, Zawar Mines., $3^{\text {rd }}$ Symposium on Rock Mechanics. Institution of Engineers (India), Rourkee, India 1983.

[6] Santharam A. Geo-technical Considerations for the estimation of ground stability at Mochia Mine. $3^{\text {rd }}$ symposium on Rock mechanics, Institution of Engineers (India), Rourkee, India 1983.
[7] Santharam A. Rock Mass Classification for Underground Metal Mines. Indian Geotechnical Journal. Indian Institute of Technology, Delhi 1988; 16: 94-106.

[8] Santharam A. Application of Rockmass Characterisation Studies in Mineral Conservation. National Seminar on Underground Metal Mining Practices, Department of Mining Engineering, Indian Institute of Technology (IIT), Kharagpur 1988.

[9] Santharam A. Geo-technics in Mine Design and Stability Assessment in Underground Base Metal Mines. $15^{\text {th }}$ World Mining Congress, Madrid, Spain (also in Institution of Mining and Metallurgy (IMM) London, UK Abstracts 1992-1993; 43: 4.

[10] Santharam A. A Computer Procedure to Simulate Progressive Rock Mass Failure in Underground Metal Mines. $23^{\text {rd }}$ International Symposium on Application of Computers in Mining and Operational Research (APCOM) Department of Mining Engineering, University Of Arizona, Tucson, Arizona, USA 1992.

[11] Sahoo KC, et al. Occurrence of PGE Mineralisation in Bangur, Kendujhar District, Odisha. Journal of Geological Society of India 2014; 83: 31-37. https://doi.org/10.1007/s12594-014-0004-7

DOI: http://dx.doi.org/10.15377/2409-5710.2017.04.4

(C) 2017 Santharam and Rao; Avanti Publishers.

This is an open access article licensed under the terms of the Creative Commons Attribution Non-Commercial License (http://creativecommons.org/licenses/by-nc/3.0/) which permits unrestricted, non-commercial use, distribution and reproduction in any medium, provided the work is properly cited. 